\title{
Non-Performing Loans, Financial Stability, and Banking Competition: Evidence for Listed and Non-Listed Eurozone Banks*
}

\author{
JOSÉ MANUEL MANSILLA FERNÁNDEZ ** \\ Universidad Pública de Navarra and INARBE
}

Received: May, 2018

Accepted: March, 2019

\begin{abstract}
This article analyses the effects of non-performing loans (NPLs hereafter) and financial (in)stability on banking competition in the Eurozone lending markets. Our results suggest that NPLs increase marginal costs and the degree of competition in banking markets. This phenomenon is economically more significant for non-listed than for listed banks. The results are robust to any endogeneity due to the impact of the economic downturn and the sovereign debt crisis on the growth of NPLs.
\end{abstract}

Keywords: Bank competition, banking and financial crisis, listed banks, NPLs, sovereign debt crisis.

JEL Classification: G01, G21, G32, H63.

\section{Introduction}

Until the onset of the financial crisis of 2008, the level of non-performing loans (NPLs) remained relatively stable. From then on, the bad loan portfolios of European banks embarked on the same downward trend as the macroeconomic environment. ${ }^{1}$ At the time of writing this paper, the NPL problem is concentrated in the so-called peripheral countries of the Eurozone. According to data published by the European Banking Authority (EBA), Eurozone bank balance sheets are still heavily weighed down by bad loans which are slowing down the lending market, and threatening financial stability. ${ }^{2}$

Banks keeping large volumes of NPLs on their balance sheets may create doubts about their viability in the event of worsening macroeconomic conditions, and increase uncertainty about

\footnotetext{
* Acknowledgements: My deepest thanks to Giorgio Barba Navaretti, Giacomo Calzolari and Alberto F. Pozzolo for their unconditional support and valuable advice during the preparation of this paper. I am also indebted to Isabel Abinzano, Santiago Carbó Valverde, Gabriella Chiesa, Pierpaolo Giannoccolo, Massimiliano Marzo, Luis Muga and Francisco Rodríguez Fernández. Responsibility for the content is entirely my own.
}

** ORCID: 0000-0002-9785-0217. 
their future profitability and asset value. Such banks are exposed to negative risk perception by market players, which could face them with costlier financing and a marginal cost increase (Chiesa and Mansilla-Fernández, 2018a,b). On the demand side, adverse macro-economic conditions, the sovereign debt crisis, and the deleveraging of the real sector may have contributed to lowering the price of loans. Analysing the market, one would expect banks affected by an increase in bad loans to reduce lending and narrow their mark-ups. In specific terms, the first question posed by this paper is: Can it be proven that bad loans and, by extension financial (in)stability, may affect the level of competition between banks in the lending market? To date, the financial literature has presented various conclusions as to the repercussions of the level of competition on financial stability (e.g., Boyd and Nicoló, 2005; Martinez-Miera and Repullo, 2010; Jiménez et al., 2013; IJtsma et al., 2017) As far as we know, this is one of the first studies to demonstrate that financial stability can affect the level of competition.

In second place, this paper investigates whether access to capital markets can mitigate the effects of the transmission mechanism described above. In specific terms, the research question could be formulated as follows: Do bad loans have the same effect on the level of competition in listed as in non-listed banks? The literature cited above reveals that larger banks -of the type sometimes described as "too big to fail" (TBTF)- and systemic banks tend to accumulate higher levels of risk than smaller ones (Cai et al., 2018; Salas and Saurina, 2002; Stern and Feldman, 2004). This paper considers the role of capital management in assessing levels of competition. ${ }^{3}$ Listed banks have greater market access capacity and greater potential to increase their capital base than is the case for non-listed banks. Non-listed banks should therefore face a higher marginal cost increase than listed banks. In line with previous studies (e.g., Accornero et al., 2017; Louzis et al., 2012; Zhang et al., 2016), this paper measures the NPL ratio as the volume of NPLs over total loans to customers. Graph 1 illustrates the motivation for this research.

\section{Graph 1 \\ EVOLUTION AND DISTRIBUTION OF THE NPL RATIO FOR LISTED VS. NON-LISTED BANKS}

(a) Evolution of the NPL ratio

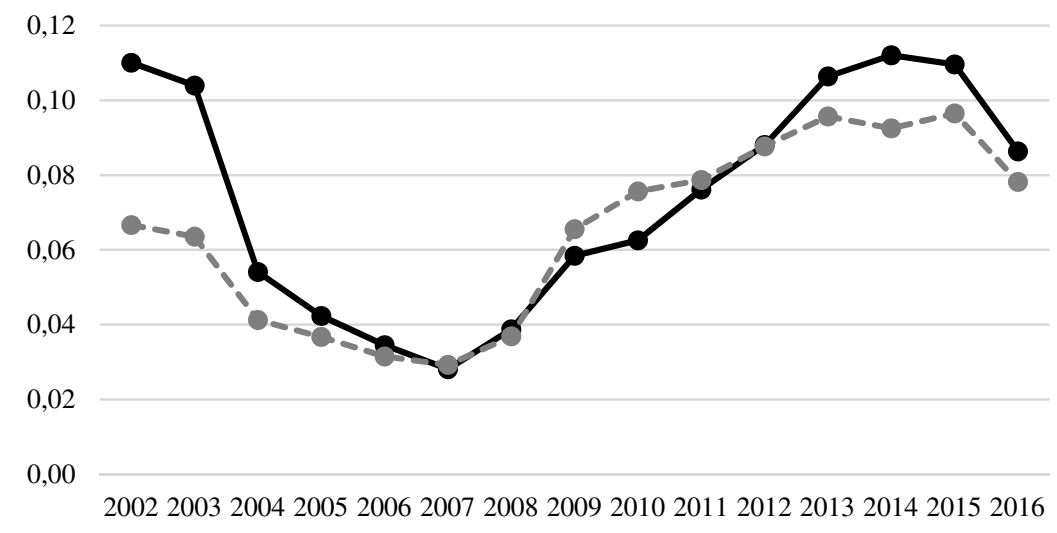

$\longrightarrow$ Listed banks $\quad-\infty$ Non-listed banks 
(Continued.)

(b) Distribution of the NPL ratio

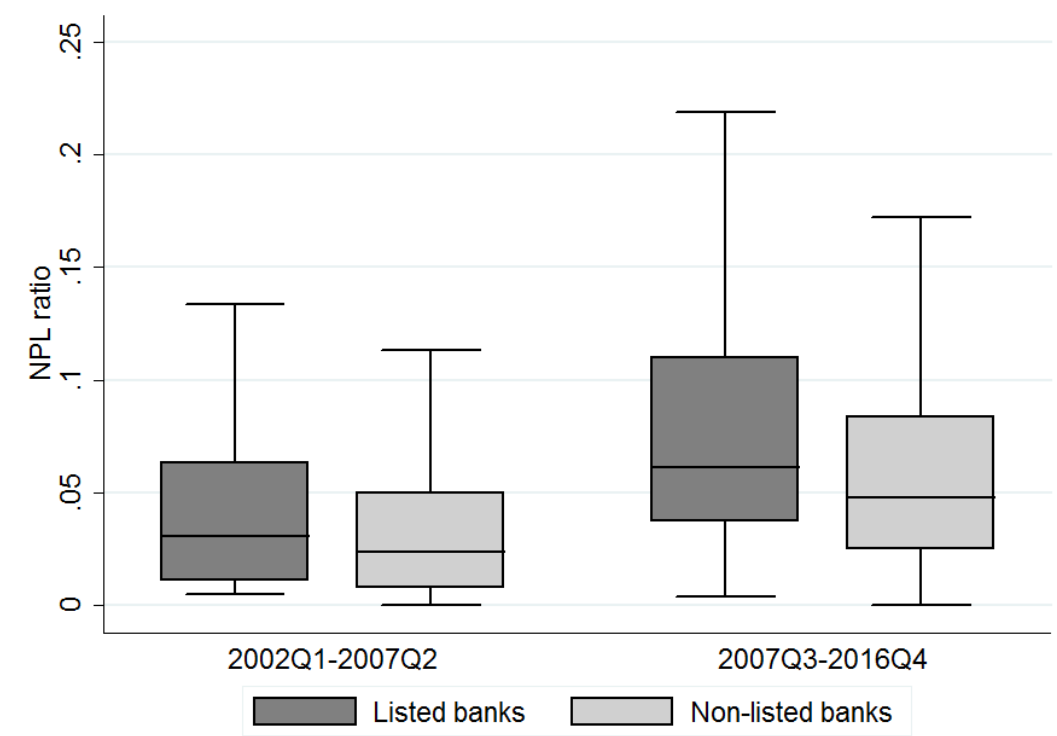

Source: Bankscope and Orbis Bank Focus (Bureau van Dijk). The NPL ratio is measured as the volume of loans to customers. Graph 1.a shows the evolution of the mean value of the NPL ratio for listed (solid line) and non-listed (broken line) banks. Graph 1.b is a box and whisker plot of the distribution of the NPL ratio for listed and non-listed banks. The whiskers show the upper and lower limits of the distribution. The line through each box indicates the median, i.e., the 50th percentile of the distribution. The upper (lower) boundaries of the box are the upper (lower) quartiles.

Graph 1.a shows that the average NPL ratios of listed banks are higher than those of non-listed banks in the period preceding the financial crisis of 2007. The slope of the time series reveals that listed banks generate NPLs at a faster rate than non-listed banks. Graph 1.b displays the distribution of the NPL ratio before (2002Q1-2007Q2) and after the onset of the financial crisis (2007Q3-2016Q4) in the form of a box and whisker plot. As the graph shows, the median listed bank holds a higher stock of NPLs than the average non-listed bank.

The empirical analysis in this paper uses a panel of high-frequency data drawn from Bankscope and Orbis Bank Focus (Bureau van Dijk) containing 388 Eurozone banks for the period 2002 to 2016. The panel is completed with market and macroeconomic data drawn from the Thomson Reuters Datastream. With respect to the variables used in the econometric analysis, financial stability is calculated using the Z-score indicator as employed in the financial literature to assess the inverse probability of bank default (Laeven and Levine, 2009; Schaeck et al., 2012; Liu et al., 2013; Köhler, 2015). In line with previous studies (Cruz-García et al., 2017, 2018; Carbó et al., 2009; Maudos and de Guevara, 2004, 2007), the degree of competition between banks is calculated using the Lerner index, which measures bank's level of market power by relating price to marginal cost. As a robustness check, this 
result is tested against the Boone (2008) indicator which measures the temporary impact of marginal cost on the bank's share in the lending market. The Ordinary Least Squares (OLS) estimator with fixed effects is used for the panel data, and the Instrumental Variables (IV) estimator is used to check whether the final result is conditioned by the effect of crisis-related factors on the NPL level. This study contributes to the research by bringing to light that higher NPL ratios increase banks' marginal cost and also lending market competition. The results suggest, furthermore, that non-listed banks are more vulnerable than listed banks to changes in NPLs.

The remainder of the paper is organized in five sections. Section two discusses the related literature. Section three presents the hypotheses, defines the database and describes the empirical model and study variables. Section four provides a discussion of the results and the paper closes with a concluding section.

\section{Literature review}

There now follows a discussion on the theoretical basis for the questions to be addressed and the methodology to be used in this research, and an explanation of how the study fits into the existing body of research.

The first question to be addressed is whether NPLs and financial (in)stability are determining factors of the levels of competition in banking markets. Until now, the economics literature has focused on the level of banking competition as a determining factor for financial stability and the amount of risk assumed by banks (e.g., Allen and Gale, 2004; Coccorese, 2004; Martinez-Miera and Repullo, 2010). ${ }^{4}$ Although these studies share the common denominator of treating banking competition and financial stability as a trade-off, their conclusions are ambiguous. On the one hand, the "competition fragility" predicts that any increase in the level of competition will reduce mark-ups and lower the franchise value of banks, causing them to increase their risk taking (IJtsma et al., 2017). The intuition behind this reasoning is simple: banks operating in relatively non-competitive markets are more able to identify the more solvent borrowers; and this allows them to increase their interest margin, capital ratios and franchise value (Coccorese, 2004). The "competition stability" view, on the other hand, predicts that banks operating in low competition settings raise loan prices to relatively uncompetitive levels, thus increasing their customers' probability of default, and thereby their own portfolio risk, while posing a threat to financial stability (Boyd and Nicoló, 2005). The empirical literature demonstrates that there is a parabolic relationship between banking competition and financial stability (Martinez-Miera and Repullo, 2010; Liu et al., 2013). This study contributes to the literature by disentangling the transmission mechanism through which the opposite occurs: that is, financial (in)stability determines banking competition. The process is explained by applying standard industrial organization models to banking markets (e.g., VanHoose, 2017). The literature leaves open the question of estimating the thresholds above which NPLs become pernicious for the proper functioning of the banking sector. With respect to the first issue, in a study conducted on a sample of Chinese banks, Zhang et al. (2016) report a threshold of around $4.8 \%$, above which banks start to exhibit 
moral hazard-type behaviour; sustaining future losses as a consequence (Hellmann et al., 2000). ${ }^{5}$ Beyond this threshold, bank profitability suffers because the resources for lending are diminished (e.g., Angelini, 2018; Angelini et al., 2017). Banks address this problem by laying up insolvency provisions as a safety net in case they need to write off some or all of their doubtful loans (Mohaddes et al., 2017; Zhang et al., 2016). The size and evolution of NPL ratios are observable data. Banks with rising NPL trends are perceived among financial market players as more being risk-taking than the rest (Accornero et al., 2017). Bank borrowers and capital investors, alike, may question the viability of such banks and hence demand non-diversifiable risk compensation (e. g., Chiesa and Mansilla-Fernández, 2018 a, b). In other words, if banks find it harder to access funding (Aiyar et al., 2015; Chiesa and Mansilla-Fernández, 2018 a), it can be assumed that the price inputs used for lending will increase, and there will be a vertical shift in the marginal cost curve (VanHoose, 2017; Degryse and Ongena, 2008).

The empirical literature studies whether the NPL transmission mechanism is static, i.e., measured in levels; or dynamic, i.e., measured as changes in the amount of NPLs on the balance sheet. This paper is closely related with that of Accornero et al. (2017) where it is shown that "change" in the NPL level rather than the NPL ratio per se, is the transmission mechanism through which the loan supply decreases. Meanwhile, Bending et al. (2014) use a dynamic approach to show how an increase in NPLs reduces the supply of loans to non-financial firms. In line with the streams of research discussed above, this study uses the dynamic approach to test whether increases in the NPL ratio work as a transmission mechanism affecting competition in the Eurozone banking markets. The results confirm that an increase in the variation of the NPL ratio causes a marginal cost increase for banks, but provide no empirical evidence that an increase (decrease) in the NPL ratio (as an indicator of financial stability) has any impact on the price of loans. ${ }^{6}$ In a monopolistic market setting, the size of the markup is limited by the fact that banks have less room for manoeuvre; which is a symptom of higher competition. The results of this study suggest, furthermore, that an upward trend in NPLs reduces lending market concentration.

The second question that this study will try to answer is whether this effect is more significant in the case of listed or non-listed banks. As far as we are aware, this is one of the first studies to investigate the repercussions of financial (in)stability on banking market competition, while taking into consideration whether the banks are listed in secondary banking markets. ${ }^{7}$ In seeking an answer to this question, this paper finds its basis in the literature highlighting the role of bank size, in particular the size of banks deemed "too-big-to-fail" (TBTF), as a transmission mechanism leading banks to engage in risky trading and increase their stock of NPLs (Cai et al., 2018; Salas and Saurina, 2002; Stern and Feldman, 2004). Stern and Feldman (2004) show that, in comparison with non-listed banks, TBTF banks are relatively less disciplined by their stakeholders, who are confident that such entities are covered by government protection schemes -i. e., deposit guarantees or the possibility of rescue in the event of failure (Boyd and Graham, 1998; Nier and Baumann, 2006). The seminal work by Boyd and Gertler (1994) shows that a policy benefiting the big US banks caused an increase in NPL levels. In a similar vein, Louzis et al. (2012), studying a sample of Greek banks, show that fulfilment, or otherwise, of the TBTF hypothesis depends on each loan cat- 
egory. Using the principal-agent theory, Rud et al. (2018) show that the bank (the agent) and the borrower (the principal) are more closely aligned in a low competition setting, where the entity has less risk exposure. However, the findings of Cai et al. (2018) show that syndicated loans, despite being extended by a group of banks, can increase systemic risk due to the effect of interconnections between banks during periods of economic recession. This research contributes to the economics literature by demonstrating that the effect of an NPL increase on marginal cost is economically more significant in non-listed than in listed banks. This can be explained by the fact that access to capital markets is more restricted for non-listed than for listed banks. By incorporating risk, non-listed banks would be accepting harsher financing conditions than those faced by listed banks, thus increasing their input costs. Non-listed banks would therefore have less lending capacity and suffer greater losses in terms of market share and mark-up than listed banks.

\section{Hypotheses, data and methodology}

\subsection{Hypotheses}

The purpose of this research is to analyse the effect of the NPL ratio on competition between banks, making a distinction between listed and non-listed banks. Based on the reviewed literature, the following hypotheses are proposed:

Hypothesis 1.-The NPL ratio increases competition in markets for bank loans.

Hypothesis 2.-The NPL ratio has a more significant impact on the level of competition for non-listed than for listed banks.

\subsection{The data}

The main sources of data for this study are Bankscope and Orbis bank Focus (Bureau van Dijk). The database is formed from quarterly data for Eurozone Banks for the period 2002Q1-2016Q4. ${ }^{8}$ The initial sample consisted of consolidated state data on commercial banks, savings banks and loan cooperatives. All the financial entities included in the sample provide data from $1^{\text {st }}$ January to $31^{\text {st }}$ December. Because Bankscope and Orbis Bank Focus make a distinction between listed and non-listed entities, a variable is extracted to allow the sample to be split into these two groups. Banks are selected at the highest possible level of consolidation, usually as banking groups, in order to avoid double-entry problems. Those that do not form banking groups are kept as individual entities. The final sample consists of 388 financial entities, of which 86 are listed and 302 are non-listed.

The sample years are considered representative because they include the years preceding the financial crisis, when banks were extending more loans and assuming higher levels of risk (2002Q1-2007Q2), as well as the years of the banking and sovereign debt crisis (2007Q32016Q4). 
Non-Performing Loans, Financial Stability, and Banking Competition: Evidence for Listed...

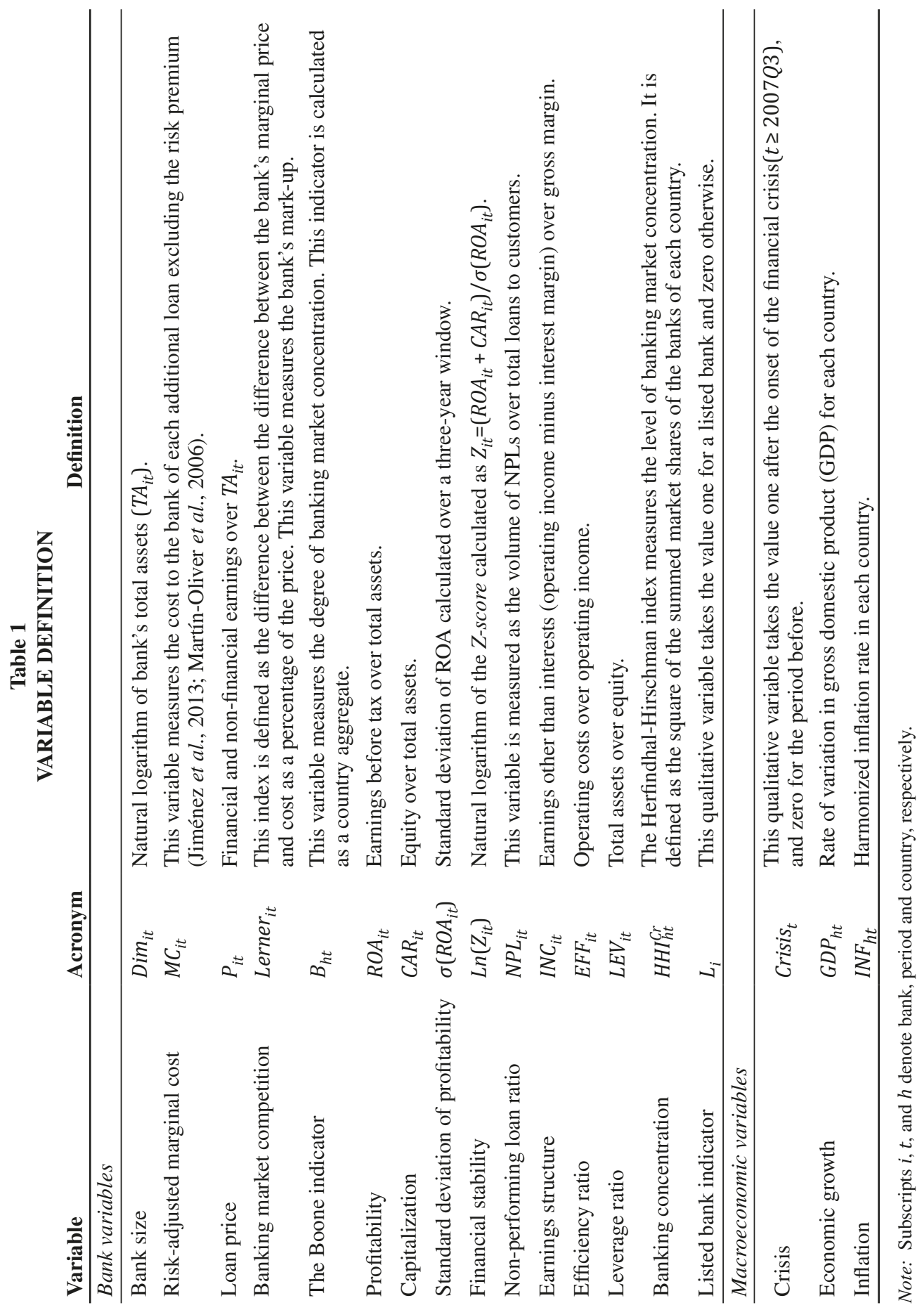


The data are expressed in thousands of Euros and deflated by the harmonized consumer price index (HCPI). Inconsistent observations, such as zero total assets, negative equity values, and zero number of workers, were removed from the sample. Finally, a panel of data comprising 23,265 observations was obtained.

The macroeconomic time series data for each country were drawn from the Thomson Reuters Datastream. The banking data and macroeconomic data were then combined into a single panel.

Table 1 contains the definitions of the study variables, which are winsorized at $1 \%$ to remove any outliers that might skew the results.

\subsection{Measures of banking competition}

This study uses the Lerner index and Boone's (2008) indicator as measures of the degree of banking market competition. Both these indicators use marginal cost as the main variable.

\subsubsection{The Lerner Index}

This study uses the risk-adjusted Lerner index as a measure of the degree of banking market competition in the Eurozone. This index measures the bank's mark-up capacity as a percentage of the price and can vary between zero and one, where Lerner $_{i t}=1$ in the case of perfect monopoly, Lerner $_{i t}=0$ in the case of perfect competition, and, exceptionally, Lerner $_{i t}<0$ in the case of non-optimal performance, in which case the bank must resort to mark-down. The Lerner index is calculated as follows:

$$
\text { Lerner }_{i t}=\frac{P_{i t}-M C_{i t}}{P_{i t}}
$$

where the subscripts $i$ and $t$ denote the bank and the time period, respectively. The variable $P_{i t}$ is calculated as the ratio of financial and non-financial revenue to total assets. $M C_{i t}$ is the marginal cost. Given that banks take the risk premium into account when setting loan prices, a higher mark-up does not necessarily indicate a lower degree of competition in the banking market, and may be due to an increase in the risk cost (Cruz-García et al., 2018). Thus, if marginal cost were estimated in the conventional manner, the Lerner index estimates could be biased. For this reason, the risk-adjusted marginal cost is estimated as follows (see Martín-Oliver et al., 2006; Jiménez et al., 2013): ${ }^{9}$

$$
M C_{i t}=\frac{r_{t}+P D_{i t}-L G D}{1-P D_{i t}-L G D}
$$

where $r_{t}$ is the risk-free interest rate measured as the quarterly average of the three-month Euribor. $P D_{i t}$ is the probability of default measured as the quotient between impairment loss on financial assets and the loan volume. ${ }^{10} L G D$ is the value of the loans the bank will be unable to recoup in the event of default. Following Jiménez et al. (2013), LGD is assigned the value 
$45 \%$, as recommended in the bank capital rules laid down by the Basel Banking Supervision Committee.

\subsubsection{The Boone (2008) indicator}

The Boone (2008) indicator is another measure of banking competition which is used as a robustness check for the Lerner index. The Boone indicator assumes that more efficient banks will gain a greater share of the market and increase their profits at the expense of less efficient entities. In other words, competition improves (worsens) the profitability of more (less) efficient Banks. It is estimated by means of the following expression:

$$
\ln \left(M S_{i t}\right)=\alpha_{0}+\sum_{t=2002 Q 1}^{2016 Q 3} \beta_{t} M C_{i t}+\sum_{t=2002 Q 1}^{2016 Q 3} \theta_{t} D_{t}+\varepsilon_{i t}
$$

where $M S_{i t}$ is the lending market share for each bank measured as the ratio of the $i$ bank's volume of customer loans to total bank loans for country $h$ in period $t$. The term $M C_{i t}$ denotes the marginal cost as defined in the section above. The matrix $D_{t}$ includes discrete time variables to control for factors common to all banks within each specific period. Coefficient $\beta_{t}$ is the Boone indicator. Negative values $\left(\beta_{t}<0\right)$ mean that more cost-efficient banks gain market share from comparatively less efficient banks. A large negative value of $\beta_{t}$ is indicative of a relatively more competitive market, while values higher than zero $\left(\beta_{0}>0\right)$ mean that higher marginal costs increase the bank's market share. Heteroscedasticity can be overcome by means of a logarithmic transformation.

\subsection{Financial stability indicators: the NPL ratio and the Z-score}

This study uses two measures of risk exposure: the NPL ratio $\left(N P L_{i t}\right)$, and, as a robustness check, the Z-score. The NPL ratio, calculated as the volume of NPLs over total customer loans, is the variable of interest. The Z-score, widely used in the literature on financial stability (e.g., Laeven and Levine, 2009; Schaeck et al., 2012; Liu et al., 2013; Köhler, 2015), is calculated as follows:

$$
Z_{i t}=\frac{R O A_{i t}+C A R_{i t}}{\sigma\left(R O A_{i t}\right)}
$$

where $R O A_{i t}$ is the profitability ratio measured as earnings before tax over total assets; $C A R_{i t}$, is the capitalization ratio measured as equity capital over total assets; and $\sigma\left(R O A_{i t}\right)$ is the standard deviation of ROA computed for a three-year rolling time window. A moving standard deviation is used to allow for time variability of the denominator.

The Z-score is interpreted as the decrease in the standard deviation of its ROA that would be required to absorb the bank's equity capital. In other words, the Z-score is the inverse probability of bank failure. 


\subsection{Empirical specification}

This section presents a discussion on strategies for identifying and testing hypotheses regarding the effects of NPLs on lending market structure.

The empirical methodology for this study is based on the following Ordinary Least Squares (OLS) estimator with fixed effects for panel data:

$$
y_{i t}=\gamma_{0}+\gamma_{1} \Delta N P L_{i, t-1}+X_{i, t-1}^{\prime} \Phi+v_{i}+\epsilon_{i t}
$$

where $y_{i t}$ is the dependent variable for the following indicators. The first is the Lerner index $\left(\right.$ Lerner $_{i t}$ ), which is computed as in expression (1). The second, used as a robustness check, is the Boone (2008) indicator, computed as shown in expression (3).

For the explanatory variables, the indicator of interest is the quarterly change in the one-period lagged NPL ratio $\left(\triangle N P L_{i t}\right)$ computed as the volume of NPLs over total customer loans. Accornero et al. (2017) show that it is not the NPL ratio, per se, but its variation that determines loan demand. Taking this finding from the literature into account, a test is performed to determine whether a change in the NPL ratio has a negative impact on banking market power. This is followed with a robustness check in which this variable is replaced with quarterly change in the natural logarithm of the $Z$-score $\left(\Delta \ln \left(Z_{i, t-1}\right)\right)$, computed as indicated in expression (4). The matrix $X_{i, t-1}^{\prime}$ captures the following control variables lagged by one period. Bank size $\left(\operatorname{Dim}_{i, t-1}\right)$ is measured as the natural logarithm of the bank's total assets. The income structure ratio $\left(I N C_{i, t-1}\right)$ is computed as the ratio of non-interest earnings (operating earnings minus the interest margin) to operating earnings and is a measure of bank revenue diversification. The efficiency ratio $\left(E F F_{i, t-1}\right)$ is calculated as operating costs over operating income and is used to control for bank (in)efficiency. Financial leverage $\left(L E V_{i, t-1}\right)$ is computed as the ratio of total assets to total equity. ${ }^{11}$ The Herfindhal-Hirschman concentration index $\left(\mathrm{HHI}_{h, t-1}^{\mathrm{Cr}}\right)$, which indicates the level of concentration in the bank lending market, is calculated as the squared sum of the market shares of banks in every country $h$. Formally, the Herfindhal-Hirschman index is calculated as $H H I_{h, t}^{C r}=\sum_{i=1}^{N}\left(M S_{i t}\right)^{2}$, where $M S_{i t}$ is the lending market share of each bank in the country in which it operates $(h)$. Standard Industrial Organization models predict equivalence between the Lerner index and the HHI, proportional to market contestability and inverse price elasticity of demand. At the empirical level, however, the HHI and the Lerner index can yield diverse results if controls for the input-output patterns of regional markets are not included (Carbó-Valverde et al., 2003, 2009; Carbó et al., 2009). Previous studies have used the HHI as a determinant of the Lerner index, although the ratio can become increasingly endogenous with growing market contestability (see, Carbó-Valverde and Rodríguez-Fernández, 2007; Maudos and de Guevara, 2004, 2007).

Macroeconomic variables are then included to control for business cycle effects on market structure. $G D P_{h t}$ denotes the quarterly rate of change in the gross domestic product of 
every country $(h)$; while the discrete variable, Crisis, , which is included to control for potential structural change, is assigned a value of one from the onset of the financial crisis onwards $(t \geq 2007 Q 3)$, and zero otherwise.

Finally, to control for possible endogeneity issues in the drivers of loan default, the NPL ratio $\left(\triangle N P L_{i t}\right)$ is instrumentalized with the macro-economic factors discussed in section 2:

$$
\Delta \widehat{N P L}_{i t}=\lambda_{0}+\lambda_{1} U N E M_{h t}+\lambda_{2} C D S_{h t}+\varpi_{i t}
$$

where $\triangle \widehat{N P L}_{i t}$ is the predicted value of the NPL ratio based on the selected instruments; $U N E M_{h t}$ is the unemployment rate for each country; $C D S_{h t}$ denotes the 10-year sovereign CDS value for each country, which is used as the country risk proxy. Since Thomson Reuters Datastream data on this variable are only available from 2008 onwards, the second part of the exercise covers the crisis period (2008Q1-2016Q4) exclusively. $\varpi_{i t}$ is the error component of the regression equation. This second exercise is approached using the instrumental variables (IV) estimation method.

\section{Results}

\subsection{Descriptive statistics and parametric tests}

A description of the sample distribution and the values registered before and after the crisis are summarized in table 2. Panel A shows the descriptive statistics of the study variables. With respect to the competition indicators, the Lerner index $\left(\right.$ Lerner $\left._{i t}\right)$ shows an average of 0.31 , oscillating between 0.10 and 0.50 ; and the Boone indicator $\left(B_{h t}\right)$ an average value of -0.16 , oscillating in the range of -0.29 to -0.05 . The Herfindhal-Hirschman index $\left(H H I_{h, t}^{C r}\right)$ for the lending market $\left(H H I_{i, t}^{C r}\right)$ shows an average of 0.37 , oscillating between approximately 0.001 and 1.00. Marginal cost $\left(M C_{i t}\right)$ shows an average of 0.03 , oscillating between 0.01 and 0.09 ; while the average price of loans $\left(P_{i t}\right)$ is 0.04 , oscillating between 0.01 and 0.14 . As far as the financial stability variables are concerned, the NPL ratio $\left(N P L_{i t}\right)$ shows an average of $8.21 \%$ for the Eurozone as a whole, oscillating approximately between $0.01 \%$ and $54.55 \%$. The quarterly variation in the NPL ratio $\left(\triangle N P L_{i t}\right)$ shows an average of 0.0034 , oscillating between -0.05 and 0.07 . The natural logarithm of the $Z$-score $\left(\operatorname{Ln}\left(Z_{i t}\right)\right)$ shows an average of 1.69 , oscillating between -5.89 and 4.96 , in line with previous findings. The quarterly variation in the variable $\left(\Delta \operatorname{Ln}\left(Z_{i t}\right)\right)$, meanwhile, shows an average of 0.007 , oscillating between -5.89 and 4.96. Finally, the average value of the dummy variable $L_{i t}$ suggests that $22.18 \%$ of the banks included in the sample are listed; which means that the mean individual is a non-listed entity.

Panel B shows the mean differences between the pre-crisis period (2002Q1-2007Q2) and the post-crisis period (2007Q32016Q4). These were obtained using the time variable, Crisis $_{t}$. The mean differences for the Lerner index $\left(\right.$ Lerner $\left._{i t}\right)$ reject the null hypothesis $\left(H_{1}\right.$ : Crisis ${ }_{t}(0)$ - Crisis $\left._{t}(1)<0\right)$ thus indicating a decline in competition following the onset of the crisis. 


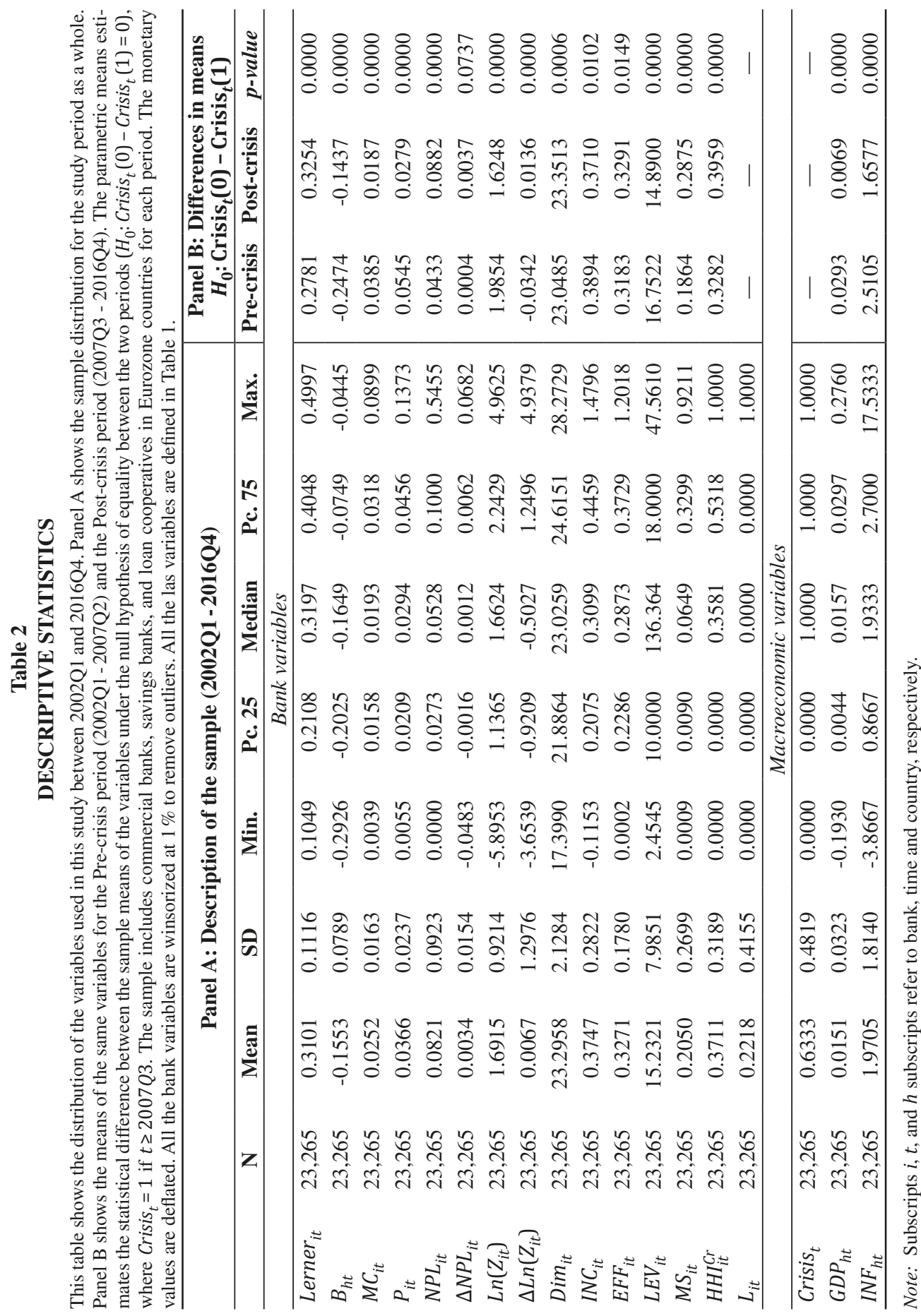


Likewise, the parametric test rejects the null for the Boone indicator $\left(B h_{t}\right)$ thereby confirming a decline in competition in the Eurozone banking markets during the post-crisis period $\left(H_{1}:\right.$ Crisis $_{t}(0)-$ Crisis $\left._{t}(1)<0\right)$. This is due to a significant drop in marginal cost $\left(M C_{i t}\right)$ and the price of loans $\left(H_{1}:\right.$ Crisis $_{t}(0)-$ Crisis $\left._{t}(1)>0\right)$, and to an increase in the lending market concentration indices $\left(M S_{i t}\right.$ and $\left.H H I_{h, t}^{C r}\right)$ during the post-crisis period $\left(H_{1}\right.$ : $\operatorname{Crisis}_{t}(0)-$ Crisis $\left._{t}(1)<0\right)$. The results for the financial stability variables support a relatively higher NPL ratio $\left(N P L_{i t}\right)$ for the post-crisis period. The mean difference results also enable rejection of the null hypothesis for the quarterly growth of the NPL ratio $\left(\triangle N P L_{i t}\right)$ in favour of the post-crisis period $\left(H_{1}: \operatorname{Crisis}_{t}(0)-\operatorname{Crisis}_{t}(1)<0\right)$. The results for the financial stability indicator $\left(\operatorname{Ln}\left(Z_{i t}\right)\right)$ remain qualitatively consistent with the those reported above, enabling rejection of the null hypothesis in favour of the pre-crisis period for the level-based indicator $\left(\Delta \operatorname{Ln}\left(Z_{i t}\right)\right)\left(H_{1}: \operatorname{Crisis}_{t}(0)-\operatorname{Crisis}_{t}(1)>0\right)$. Analysis of the overall results of the parametric hypothesis test by sub-periods shows that the crisis:

i. Reduces competition in the bank lending markets of the Eurozone as a result of the banking integration processes carried out in several countries. ${ }^{12}$

ii. Reduces financial stability because adverse macroeconomic conditions trigger an increase in NPLs, leading to a drop in bank earnings, and, in some cases, even to losses.

\subsection{The baseline regression}

This section discusses the econometric results which prove hypothesis 1 . Table 3 gives the regression coefficients for expression (5). The hypotheses for this study are tested using OLS regression analysis with fixed effects for panel data (columns (1)-(4)). The estimation results show that a $1 \%$ increase of variation in the NPL ratio $\left(\Delta N P L_{i t}\right)$ triggers significant reductions in the Lerner index (Lerner ${ }_{i t}$ ) and the Boone indicator (of $0.75 \%$ and $0.54 \%$, respectively). This result is robust to replacing $\triangle N P L_{i t}$ with the variation in the natural logarithm of the $Z$-score $\left(\Delta \operatorname{Ln}\left(Z_{i t}\right)\right)$. The estimates suggest that a $1 \%$ increase in $\Delta \operatorname{Ln}\left(Z_{i t}\right)$ causes Lerner $_{i t}$ and $B_{h t}$ to grow by $0.72 \%$ and $0.26 \%$ (p-value $\left.<0,000\right)$, respectively. The results of this study show that a growing trend in the amount of risk held on bank balance sheets, due either to an increase in NPLs or to a lack of liquidity or a drop in earnings, has a positive impact on the degree of competition in the lending markets of the Eurozone. The control variables have the expected signs and significance levels.

The results reported above are robust to the inclusion of instrumental variables (IV), as shown in expression (6), to control for the effect of the economic crisis on the growth of the NPL ratio (e.g., Balgova et al., 2016, 2018; Buch et al., 2016; Ghosh, 2017; Podstawski and Velinov, 2018). The estimates of the instrumental variables are given in columns (5)-(8). The sign and magnitude of the IV estimator support the notion that the degree of competition in banking markets is sensitive to increases in the NPL ratio and to financial (in)stability. Furthermore, the first-stage analysis fulfils initial expectations by confirming that the unemployment rate $\left(U_{N E M} M_{h, t-1}\right)$ and 10-year sovereign CDS $\left(C D S_{h t-1}\right)$ drive NPL growth. 


\section{Table 3}

\section{THE EFFECTS OF BANK NPLS AND FINANCIAL STABILITY ON THE LEVEL OF COMPETITION}

This table shows the results when a variation in financial stability, defined as the NPL ratio $\left(N P L_{i t}\right)$ and the natural logarithm of the $Z$-score $\left(\operatorname{Ln}\left(Z_{i t}\right)\right)$, is regressed against the Lerner index $\left(\right.$ Lerner $\left._{i t}\right)$ and the Boone indicator $\left(B_{h t}\right)$, as dependent variables. The regressions are estimated using high-frequency data. $L_{i} i$ is a qualitative variable which is equal to one if bank $i$ is listed, and zero otherwise. Specifications (1), (2), (3) and (4) are estimated using the Ordinary Least Squares (OLS) estimator for panel data with fixed effects for the period 2002Q1-2016Q4. Specifications (5), (6), (7) and (8) are estimated using the instrumental variables (VI) estimator for the period 2008Q1-2016Q4. The selected instruments are the NPL ratio $\left(N P L_{i t}\right)$, the unemployment rate $\left(U N E M_{h \cdot t-1}\right)$ and the 10 -year sovereign CDS $\left(C D S_{h: t-1}\right)$ lagged by one quarter for country $h$. Instruments validated by Sargan test, under the null of exogeneity, checking the lack of correlation between the instruments and the error term of the main equation. All the regressions contain individual fixed effects, and the standard errors are clustered by countries. *, **, ***, denote minimum $10 \%$, $5 \%, 1 \%$ significance, respectively.

\begin{tabular}{|c|c|c|c|c|c|c|c|c|}
\hline & \multicolumn{4}{|c|}{ OLS with fixed effect } & \multicolumn{4}{|c|}{ IV with fixed effect } \\
\hline & $\begin{array}{c}\text { Lerner }_{i t} \\
\text { (1) }\end{array}$ & $\begin{array}{l}\text { Lerner }_{i t} \\
\text { (2) }\end{array}$ & $\begin{array}{l}B_{h t} \\
(3)\end{array}$ & $\begin{array}{l}B_{h t} \\
(4)\end{array}$ & $\begin{array}{l}\text { Lerner }_{i t} \\
\text { (5) }\end{array}$ & $\begin{array}{c}\text { Lerner }_{i t} \\
\text { (6) }\end{array}$ & $\begin{array}{l}B_{h t} \\
(7)\end{array}$ & $\begin{array}{l}B_{h t} \\
(8)\end{array}$ \\
\hline$\overline{\Delta N P L_{i t}}$ & $\begin{array}{l}-0.745 * * * \\
(0.088)\end{array}$ & & $\begin{array}{l}-0.542 * * * \\
(0.129)\end{array}$ & & $\begin{array}{l}-0.526 * * * \\
(0.089)\end{array}$ & & $\begin{array}{l}-0.425 * * * \\
(0.072)\end{array}$ & \\
\hline$\Delta \operatorname{Ln}\left(Z_{i t}\right)$ & & $\begin{array}{l}0.718 * * * \\
(0.086)\end{array}$ & & $\begin{array}{l}0.258 * * \\
(0.100)\end{array}$ & & $\begin{array}{l}0.517 * * * \\
(0.083)\end{array}$ & & $\begin{array}{l}0.397 * * * \\
(0.074)\end{array}$ \\
\hline $\operatorname{Dim}_{i, t-1}$ & $\begin{array}{l}0.433 * * * \\
(0.120)\end{array}$ & $\begin{array}{l}0.478 * * * \\
(0.163)\end{array}$ & $\begin{array}{l}0.315 * * * \\
(0.040)\end{array}$ & $\begin{array}{l}0.341 * * * \\
(0.039)\end{array}$ & $\begin{array}{l}0.499 * * * \\
(0.063)\end{array}$ & $\begin{array}{l}0.473 * * * \\
(0.061)\end{array}$ & $\begin{array}{l}0.453 * * * \\
(0.052)\end{array}$ & $\begin{array}{l}0.536 * * * \\
(0.065)\end{array}$ \\
\hline $\operatorname{Dim}_{i, t-1}^{2}$ & $\begin{array}{l}-0.049 * * * \\
(0.012)\end{array}$ & $\begin{array}{l}-0.051 * * * \\
(0.014)\end{array}$ & $\begin{array}{l}-0.050 * * * \\
(0.012)\end{array}$ & $\begin{array}{l}-0.059 * * * \\
(0.012)\end{array}$ & $\begin{array}{l}-0.055^{* * * *} \\
(0.013)\end{array}$ & $\begin{array}{l}-0.061 * * * \\
(0.012)\end{array}$ & $\begin{array}{l}-0.062 * * * \\
(0.013)\end{array}$ & $\begin{array}{l}-0.060 * * * \\
(0.012)\end{array}$ \\
\hline$I N C_{i, t-1}$ & $\begin{array}{l}0.628 * * \\
(0.209)\end{array}$ & $\begin{array}{l}0.630 * * \\
(0.139)\end{array}$ & $\begin{array}{l}0.117 * * \\
(0.042)\end{array}$ & $\begin{array}{c}0.070 * \\
(0.033)\end{array}$ & $\begin{array}{l}0.641 * * \\
(0.181)\end{array}$ & $\begin{array}{c}0.461 * \\
(0.113)\end{array}$ & $\begin{array}{l}-0.436^{*} \\
(0.121)\end{array}$ & $\begin{array}{l}-0.377 * \\
(0.193)\end{array}$ \\
\hline$E F F_{i, t-1}$ & $\begin{array}{l}-0.424 * * * \\
(0.072)\end{array}$ & $\begin{array}{l}-0.429 * * * \\
(0.073)\end{array}$ & $\begin{array}{l}-0.306 * * * \\
(0.039)\end{array}$ & $\begin{array}{l}-0.311 * * * \\
(0.066)\end{array}$ & $\begin{array}{l}-0.445 * * * \\
(0.053)\end{array}$ & $\begin{array}{l}-0.448 * * * \\
(0.050)\end{array}$ & $\begin{array}{l}-0.425 * * * \\
(0.052)\end{array}$ & $\begin{array}{l}-0.414 * * * \\
(0.052)\end{array}$ \\
\hline$L E V_{i, t-1}$ & $\begin{array}{l}-0.073 * * * \\
(0.012)\end{array}$ & $\begin{array}{l}-0.072 * * * \\
(0.014)\end{array}$ & $\begin{array}{l}-0.071 * * * \\
(0.014)\end{array}$ & $\begin{array}{l}-0.068 * * * \\
(0.012)\end{array}$ & $\begin{array}{l}-0.072 * * * \\
(0.007)\end{array}$ & $\begin{array}{l}-0.075 * * * \\
(0.011)\end{array}$ & $\begin{array}{l}-0.074 * * * \\
(0.008)\end{array}$ & $\begin{array}{l}-0.079 * * * \\
(0.007)\end{array}$ \\
\hline$H H I_{h, t-1}^{C r}$ & $\begin{array}{l}0.639 * * \\
(0.187)\end{array}$ & $\begin{array}{l}0.639 * * \\
(0.183)\end{array}$ & $\begin{array}{l}0.538 * * \\
(0.134)\end{array}$ & $\begin{array}{l}0.601 * * \\
(0.162)\end{array}$ & $\begin{array}{l}0.621 * * \\
(0.140)\end{array}$ & $\begin{array}{l}0.618 * * \\
(0.131)\end{array}$ & $\begin{array}{l}0.616 * * \\
(0.134)\end{array}$ & $\begin{array}{l}0.641^{* *} * \\
(0.140)\end{array}$ \\
\hline$\left(H H I_{h, t-1}^{C r}\right)^{2}$ & $\begin{array}{l}-0.126 * * * \\
(0.013)\end{array}$ & $\begin{array}{l}-0.121 * * * \\
(0.016)\end{array}$ & $\begin{array}{l}-0.212 * * * \\
(0.019)\end{array}$ & $\begin{array}{l}0.214 * * * \\
(0.018)\end{array}$ & $\begin{array}{l}-0.134 * * * \\
(0.018)\end{array}$ & $\begin{array}{l}-0.197 * * * \\
(0.016)\end{array}$ & $\begin{array}{l}-0.152 * * * \\
(0.016)\end{array}$ & $\begin{array}{l}-0.154 * * * \\
(0.018)\end{array}$ \\
\hline$G D P_{h t}$ & $\begin{array}{l}0.568 * * \\
(0.124)\end{array}$ & $\begin{array}{l}0.511 * * \\
(0.110)\end{array}$ & $\begin{array}{l}0.484 * * \\
(0.189)\end{array}$ & $\begin{array}{l}0.452 * * \\
(0.166)\end{array}$ & $\begin{array}{l}0.596 * * * \\
(0.117)\end{array}$ & $\begin{array}{l}0.527 * * * \\
(0.104)\end{array}$ & $\begin{array}{l}-0.573 * * * \\
(0.113)\end{array}$ & $\begin{array}{l}-0.692 * * * \\
(0.115)\end{array}$ \\
\hline$I N F_{h, t-1}$ & $\begin{array}{l}-0.151 * * * \\
(0.028)\end{array}$ & $\begin{array}{l}-0.150 * * \\
(0.025)\end{array}$ & $\begin{array}{l}-0.116 * * * \\
(0.004)\end{array}$ & $\begin{array}{l}-0.109 * * * \\
(0.009)\end{array}$ & $\begin{array}{l}-0.152 * * * \\
(0.029)\end{array}$ & $\begin{array}{l}-0.148 * * * \\
(0.024)\end{array}$ & $\begin{array}{l}-0.147 * * * \\
(0.026)\end{array}$ & $\begin{array}{l}-0.152 * * * \\
(0.024)\end{array}$ \\
\hline \multirow[t]{2}{*}{ Crisis $_{t}$} & $\begin{array}{l}-0.092 * * * \\
(0.014)\end{array}$ & $\begin{array}{l}-0.099 * * * \\
(0.012)\end{array}$ & $\begin{array}{l}-0.074 * * * \\
(0.014)\end{array}$ & $\begin{array}{l}-0.076 * * * \\
(0.013)\end{array}$ & & & & \\
\hline & & & & & \multicolumn{4}{|c|}{ First step } \\
\hline $\operatorname{UNEM}_{h, t-1}$ & & & & & $\begin{array}{l}0.012 * * * \\
(0.003)\end{array}$ & $\begin{array}{l}0.013 * * * \\
(0.003)\end{array}$ & $\begin{array}{l}0.032 * * * \\
(0.003)\end{array}$ & $\begin{array}{l}0.026 * * * \\
(0.003)\end{array}$ \\
\hline$C D S_{h, t-1}$ & & & & & $\begin{array}{l}0.001 * * * \\
(0.000)\end{array}$ & $\begin{array}{l}0.001 * * * \\
(0.000)\end{array}$ & $\begin{array}{l}0.001 * * * \\
(0.000)\end{array}$ & $\begin{array}{l}0.001 * * * \\
(0.000)\end{array}$ \\
\hline$N$ & 5,160 & 5,160 & 5,160 & 5,160 & 5,160 & 5,160 & 5,160 & 5,160 \\
\hline $\begin{array}{l}\text { Sargan test } \\
{[p \text {-value }]} \\
\end{array}$ & & & & & 0.284 & 0.142 & 0.231 & 0.546 \\
\hline $\begin{array}{l}\text { Wald test } \\
{[p \text {-value }]}\end{array}$ & 0.000 & 0.000 & 0.000 & 0.000 & 0.000 & 0.000 & 0.000 & 0.000 \\
\hline
\end{tabular}




\subsection{Explaining the transmission mechanism}

The next question to arise in the light of the above results concerns the mechanism through which variations in the NPL ratio and in financial (in)stability modify the level of banking market competition. Previous studies have shown that banks with relatively high NPL levels have opted to gamble for resurrection by giving riskier loans (e. g., Hellmann et al., 2000). This study contributes to the literature by analysing the effect of variations in the NPL ratio on banks' marginal costs $\left(M C_{i t}\right)$, loan prices $\left(P_{i t}\right)$ and shares in the lending market $\left(M S_{i t}\right)$. Table 4 reports the OLS estimates for panel data with fixed effects.

Table 4

\section{THE EFFECTS OF BANK NPLS AND FINANCIAL STABILITY ON MARGINAL COST, LOAN INTEREST RATES AND MAKET SHARE}

This table shows the results when a variation in financial stability, defined as the NPL ratio $\left(N P L_{i t}\right)$ and the natural logarithm of the Z-score $\left(\operatorname{Ln}\left(Z_{i t}\right)\right)$, regressed against marginal cost $\left(M C_{i t}\right)$, loan price $\left(P_{i t}\right)$, and market share $\left(M S_{i t}\right)$ as dependent variables. Specifications (1), (2), (3), (4), (5) and (6) are estimated using the Ordinary Least Squares (OLS) estimator for panel data with fixed effects for the period 2002Q1-2016Q4. All the regressions contain individual fixed effects, and the standard errors are clustered by countries. *, **, *** denote minimum $10 \%, 5 \%, 1 \%$ significance, respectively.

\begin{tabular}{|c|c|c|c|c|c|c|}
\hline & \multicolumn{2}{|c|}{$M C_{i t}$} & \multicolumn{2}{|c|}{$P_{i t}$} & \multicolumn{2}{|c|}{$M S_{i t}$} \\
\hline & (1) & (2) & (3) & (4) & (5) & (6) \\
\hline$\Delta N P L_{i t}$ & $\begin{array}{l}0.005^{* *} \\
(0.002)\end{array}$ & & $\begin{array}{l}-0.065 \\
(0.049)\end{array}$ & & $\begin{array}{l}-0.327 * * * \\
(0.033)\end{array}$ & \\
\hline$\Delta \operatorname{Ln}\left(Z_{i t}\right)$ & & $\begin{array}{l}-0.002 * * \\
(0.001)\end{array}$ & & $\begin{array}{l}-0.001 \\
(0.002)\end{array}$ & & $\begin{array}{l}0.315 * * * \\
(0.029)\end{array}$ \\
\hline $\operatorname{Dim}_{i, t-1}$ & $\begin{array}{l}-0.045 * * * \\
(0.007)\end{array}$ & $\begin{array}{l}-0.037 * * * \\
(0.009)\end{array}$ & $\begin{array}{c}0.025^{*} \\
(0.012)\end{array}$ & $\begin{array}{c}0.028 * \\
(0.014)\end{array}$ & $\begin{array}{l}0.247 * * * \\
(0.047)\end{array}$ & $\begin{array}{l}0.293 * * * \\
(0.042)\end{array}$ \\
\hline $\operatorname{Dim}_{i, t-1}^{2}$ & $\begin{array}{l}0.021 * * * \\
(0.006)\end{array}$ & $\begin{array}{l}0.017 * * * \\
(0.005)\end{array}$ & $\begin{array}{l}-0.001 * \\
(0.000)\end{array}$ & $\begin{array}{l}-0.001 * \\
(0.000)\end{array}$ & $\begin{array}{l}-0.534 * * * \\
(0.054)\end{array}$ & $\begin{array}{l}-0.523 * * * \\
(0.052)\end{array}$ \\
\hline$I N C_{i, t-1}$ & $\begin{array}{l}-0.035^{* *} \\
(0.014)\end{array}$ & $\begin{array}{l}-0.024 * * \\
(0.011)\end{array}$ & $\begin{array}{l}0.064 * * \\
(0.024)\end{array}$ & $\begin{array}{l}0.060 * * \\
(0.023)\end{array}$ & $\begin{array}{l}0.210^{* * * *} \\
(0.055)\end{array}$ & $\begin{array}{l}0.245^{* * * *} \\
(0.048)\end{array}$ \\
\hline$E F F_{i, t-1}$ & $\begin{array}{l}0.131 * * * \\
(0.026)\end{array}$ & $\begin{array}{l}0.128 * * * \\
(0.025)\end{array}$ & $\begin{array}{l}0.026 * * \\
(0.009)\end{array}$ & $\begin{array}{l}0.016 * * * \\
(0.005)\end{array}$ & $\begin{array}{l}-0.238 * * * \\
(0.075)\end{array}$ & $\begin{array}{l}-0.228 * * * \\
(0.073)\end{array}$ \\
\hline$L E V_{i, t-1}$ & $\begin{array}{l}0.051 * * * \\
(0.012)\end{array}$ & $\begin{array}{l}0.063 * * * \\
(0.013)\end{array}$ & $\begin{array}{l}-0.048 * * \\
(0.017)\end{array}$ & $\begin{array}{l}-0.043 * * \\
(0.018)\end{array}$ & $\begin{array}{l}-0.082 * * * \\
(0.012)\end{array}$ & $\begin{array}{l}-0.081 * * * \\
(0.011)\end{array}$ \\
\hline$H H I_{h, t-1}^{C r}$ & $\begin{array}{l}-0.248 * * * \\
(0.001)\end{array}$ & $\begin{array}{l}-0.214 * * * \\
(0.002)\end{array}$ & $\begin{array}{l}0.040 * * \\
(0.012)\end{array}$ & $\begin{array}{l}0.036^{* * *} \\
(0.014)\end{array}$ & & \\
\hline$\left(H H I_{h, t-1}^{C r}\right)^{2}$ & $\begin{array}{l}0.064 * * * \\
(0.011)\end{array}$ & $\begin{array}{l}0.053 * * \\
(0.022)\end{array}$ & $\begin{array}{l}-0.034 \\
(0.027)\end{array}$ & $\begin{array}{c}0.036 \\
(0.025)\end{array}$ & & \\
\hline$G D P_{h t}$ & $\begin{array}{l}-0.211 * * * \\
(0.031)\end{array}$ & $\begin{array}{l}-0.227 * * * \\
(0.032)\end{array}$ & $\begin{array}{l}0.088^{* *} \\
(0.029)\end{array}$ & $\begin{array}{l}0.094 * * * \\
(0.022)\end{array}$ & $\begin{array}{l}0.142 * * \\
(0.083)\end{array}$ & $\begin{array}{l}0.156^{* *} \\
(0.097)\end{array}$ \\
\hline$I N F_{h, t-1}$ & $\begin{array}{l}0.021 * * * \\
(0.005)\end{array}$ & $\begin{array}{l}0.023 * * * \\
(0.008)\end{array}$ & $\begin{array}{l}0.002 * * \\
(0.001)\end{array}$ & $\begin{array}{l}0.001 * * \\
(0.000)\end{array}$ & $\begin{array}{l}-0.085 * * * \\
(0.013)\end{array}$ & $\begin{array}{l}-0.087 * * * \\
(0.016)\end{array}$ \\
\hline Crisis $_{t}$ & $\begin{array}{l}0.037 * * * \\
(0.001)\end{array}$ & $\begin{array}{l}0.037 * * * \\
(0.001)\end{array}$ & $\begin{array}{l}-0.006 * * * \\
(0.001)\end{array}$ & $\begin{array}{l}-0.003 * * * \\
(0.001)\end{array}$ & $\begin{array}{l}-0.155^{* * * *} \\
(0.076)\end{array}$ & $\begin{array}{l}-0.171 * * \\
(0.075)\end{array}$ \\
\hline$N$ & 5,160 & 5,160 & 5,160 & 5,160 & 5,160 & 5,160 \\
\hline $\begin{array}{l}\text { Wald test } \\
{[p \text {-value }]}\end{array}$ & 0.000 & 0.000 & 0.000 & 0.000 & 0.000 & 0.000 \\
\hline
\end{tabular}


Columns (1)-(2) give the estimates of the regression for banks' marginal costs, which suggest that a variation in the NPL ratio $\left(\triangle N P L_{i t}\right)$ increases the marginal cost by $0.005 \%$ ( $p$-value $<0.005)$. They also reveal that an increase in financial stability $\left(\Delta \operatorname{Ln}\left(Z_{i t}\right)\right)$, or, equivalently, a reduction in the bank's default risk, reduces the marginal cost by $0.002 \%$. It should be noted that data on the evolution of the NPL ratio and the default risk and profitability ratios are readily observable by the bank's borrowers and investors. If these perceive the bank to be gradually increasing its risk ratio, they might compromise its future profitability and asset value by demanding more compensation for the extra non-diversifiable risk (Chiesa and Mansilla-Fernández, 2018 a,b). Put another way, the accumulation of risk increases the bank's input costs, thereby increasing the marginal cost of loans. The diminishing demand trend may have put downward pressure on loan prices (BdE, 2017). The results of this study provide no empirical evidence to suggest that an increase in the NPL ratio had any effect on loan prices $\left(P_{i t}\right)$ [columns (3)-(4)]. This may be due to the influence of a reduction in the demand for loans resulting from the economic slowdown and the process of deleverage in the real sector (e.g., Balgova et al., 2016, 2018; Ghosh, 2017; BdE, 2017). Finally, the estimates shown in columns (5)-(6) confirm that an increase in bank NPLs reduces banks' lending market shares $\left(M S_{i t}\right)$. An overall analysis of the results enables the conclusion that the accumulation of risk on bank balance sheets, as shown by an increase in the NPL or default risk ratio, drives lending market competition by reducing cost efficiency. As a result, some banks suffer a loss of market share to more efficient banks, and thus see a reduction in their mark-up.

\subsection{Listed vs. non-listed banks}

This section discusses the statistics confirming hypothesis 2 . The sample is split by creating a qualitative variable $\left(L_{i}\right)$ which takes the value one if the shares of bank $i$ are listed in the secondary markets $\left(L_{i}=1\right)$, and zero otherwise $\left(L_{i}=0\right)$. Table 5 reports a parametric means test for the main study variables under the null hypothesis of equality between non-listed and listed banks $\left(H_{0}: L_{i}(0)-L_{i}(1)=0\right)$. The data were also split into a pre-crisis period (2002Q1-2007Q2) and a post-crisis period (2007Q3-2016Q4). The test results indicate that the differences in the Lerner index $\left(\right.$ Lerner $_{i t}$ ) between listed and non-listed banks emerge during the pre-crisis period, but fail to reject the null hypothesis for the crisis period. It is important to note that the test rejects the null for the marginal cost $\left(M C_{i t}\right)$, thereby indicating that non-listed banks are comparatively less efficient than listed banks during the crisis period $\left(H_{1}: L_{i}(0)-L_{i}(1)<0\right)$.

According to the above results, the parametric test shows that listed banks are relatively larger $\left(\operatorname{Dim}_{i t}\right)$ and hold less risk $\left(L E V_{i t}\right)$ than non-listed banks. Furthermore, the results for the NPL ratio $\left(N P L_{i t}\right)$ suggest that the differences between the two types of bank arise after the onset of crisis, the mean value of this variable being higher for listed than for non-listed banks. Meanwhile, the difference-in-means test fails to reject the null hypothesis for the quarterly rate of variation in the NPL ratio $\left(\triangle N P L_{i t}\right)$, thereby indicating that NPL growth is similar in both types of banks. However, the difference-in-means test reveals a relatively higher financial stability indicator $\left(\operatorname{Ln}\left(Z_{i t}\right)\right)$ for the non-listed than for the listed banks $\left(\mathrm{H}_{1}\right.$ : $L_{i}(0)-L_{i}(1)>0$ ) during both periods, while failing to reject the null for the quarterly rate of 
variation in the financial stability indicator $\left(\operatorname{Ln}\left(Z_{i t}\right)\right.$ ) (see Salas and Saurina, 2002; Louzis et al., 2012; Cai et al., 2018). ${ }^{13}$

Table 5

PARAMETRIC MEANS TEST FOR LISTED VS. NON-LISTED BANKS

This table splits the sample into two groups of individuals: listed banks $\left(L_{i}=1\right)$ and non-listed banks $\left(L_{i}=0\right)$. The parametric test is conducted under the null hypothesis $H_{0}=L_{i}(0)-L_{i}(1)=0$ for the pre-crisis period (2002Q1-2007Q2) and post-crisis period (2007Q3-2016Q4). All the variables are defined in Table 1. The coefficients are for the mean values, while the standard error is given in parentheses. The $p$-value of the Student- $t$ statistic is shown in the third column of each period of analysis.

\begin{tabular}{|c|c|c|c|c|c|c|}
\hline & \multicolumn{3}{|c|}{ Pre-crisis (2002Q1-2007Q2) } & \multicolumn{3}{|c|}{ Post-crisis (2007Q3-2016Q4) } \\
\hline & $L_{i}=0$ & $L_{i}=1$ & $p$-value & $L_{i}=0$ & $L_{i}=1$ & $p$-value \\
\hline Lerner $_{i t}$ & $\begin{array}{c}0.2514 \\
(0.0186)\end{array}$ & $\begin{array}{c}0.2905 \\
(0.0131)\end{array}$ & 0.0470 & $\begin{array}{c}0.3176 \\
(0.0123)\end{array}$ & $\begin{array}{c}0.3307 \\
(0.0099)\end{array}$ & 0.2043 \\
\hline$M S_{i t}$ & $\begin{array}{c}0.2744 \\
(0.0159)\end{array}$ & $\begin{array}{c}0.3137 \\
(0.0212)\end{array}$ & 0.0736 & $\begin{array}{c}0.1749 \\
(0.0059)\end{array}$ & $\begin{array}{c}0.2063 \\
(0.0079)\end{array}$ & 0.0007 \\
\hline$N P L_{i t}$ & $\begin{array}{c}0.0415 \\
(0.0037)\end{array}$ & $\begin{array}{c}0.0465 \\
(0.0043)\end{array}$ & 0.1998 & $\begin{array}{c}0.0845 \\
(0.0030)\end{array}$ & $\begin{array}{c}0.0943 \\
(0.0035)\end{array}$ & 0.0194 \\
\hline$\Delta N P L_{i t}$ & $\begin{array}{c}0.0027 \\
(0.0032)\end{array}$ & $\begin{array}{l}-0.0019 \\
(0.0014)\end{array}$ & 0.0944 & $\begin{array}{c}0.0030 \\
(0.0017)\end{array}$ & $\begin{array}{c}0.0039 \\
(0.0007)\end{array}$ & 0.2953 \\
\hline $\operatorname{Ln}\left(Z_{i t}\right)$ & $\begin{array}{c}2.0903 \\
(0.0425)\end{array}$ & $\begin{array}{c}1.6142 \\
(0.1353)\end{array}$ & 0.0000 & $\begin{array}{c}1.6491 \\
(0.0206)\end{array}$ & $\begin{array}{c}1.5454 \\
(0.0324)\end{array}$ & 0.0061 \\
\hline$\Delta \operatorname{Ln}\left(Z_{i t}\right)$ & $\begin{array}{l}-0.0265 \\
(0.1386)\end{array}$ & $\begin{array}{l}-0.0589 \\
(0.2482)\end{array}$ & 0.4549 & $\begin{array}{c}0.0179 \\
(0.0501)\end{array}$ & $\begin{array}{c}0.0021 \\
(0.0768)\end{array}$ & 0.4333 \\
\hline$M C_{i t}$ & $\begin{array}{c}0.0381 \\
(0.0018)\end{array}$ & $\begin{array}{c}0.0386 \\
(0.0012)\end{array}$ & 0.4008 & $\begin{array}{c}0.0163 \\
(0.0004)\end{array}$ & $\begin{array}{c}0.0205 \\
(0.0017)\end{array}$ & 0.0246 \\
\hline$P_{i t}$ & $\begin{array}{c}0.0518 \\
(0.0028)\end{array}$ & $\begin{array}{c}0.0558 \\
(0.0021)\end{array}$ & 0.1354 & $\begin{array}{c}0.0241 \\
(0.0007)\end{array}$ & $\begin{array}{c}0.0305 \\
(0.0024)\end{array}$ & 0.0192 \\
\hline $\operatorname{Dim}_{i t}$ & $\begin{array}{c}22.5387 \\
(0.0959)\end{array}$ & $\begin{array}{c}24.0611 \\
(0.1422)\end{array}$ & 0.0000 & $\begin{array}{c}22.8102 \\
(0.0446)\end{array}$ & $\begin{array}{c}24.2896 \\
(0.0673)\end{array}$ & 0.0000 \\
\hline$I N C_{i t}$ & $\begin{array}{c}0.3897 \\
(0.0089)\end{array}$ & $\begin{array}{c}0.3884 \\
(0.0132)\end{array}$ & 0.4689 & $\begin{array}{c}0.3711 \\
(0.0040)\end{array}$ & $\begin{array}{c}0.3712 \\
(0.0063)\end{array}$ & 0.4904 \\
\hline$E F F_{i t}$ & $\begin{array}{c}0.3212 \\
(0.0045)\end{array}$ & $\begin{array}{c}0.3096 \\
(0.0076)\end{array}$ & 0.1973 & $\begin{array}{c}0.3358 \\
(0.0027)\end{array}$ & $\begin{array}{c}0.3062 \\
(0.0037)\end{array}$ & 0.0000 \\
\hline$L E V_{i t}$ & $\begin{array}{c}16.1694 \\
(0.3921)\end{array}$ & $\begin{array}{c}17.9097 \\
(0.4699)\end{array}$ & 0.0036 & $\begin{array}{c}14.2135 \\
(0.1858)\end{array}$ & $\begin{array}{c}16.0630 \\
(0.2501)\end{array}$ & 0.0000 \\
\hline
\end{tabular}

Table 6 gives the results of a repeat econometric test, with separate regressions for listed $\left(L_{i}=1\right)$ and non-listed $\left(L_{i}=0\right)$ banks, aimed at checking for any significant differences in the coefficients for the two groups. The results shown in Panel A suggest that the impact of the NPL ratio on the level of banking competition $\left(\right.$ Lerner $_{i t}$ ) is economically more significant for listed than for non-listed banks. A robustness check including the natural logarithm of the $Z$-score $\left(\Delta \operatorname{Ln}\left(Z_{i t}\right)\right)$ as a regressor confirms these findings. The robustness of the above results is tested in eight alternative estimations, shown in Panel B, where Lerner $_{i t}$ is replaced with $B_{h t}$ as the dependent variable. The results are qualitatively similar to those obtained with the Lerner index. The results of the analysis of the transmission mechanism in Panel $\mathrm{C}$ confirm that bank NPLs and financial instability cause a greater increase in marginal cost $\left(M C_{i t}\right)$ in non-listed banks than in those that are listed. 


\section{Table 6}

\section{THE EFFECTS OF NPLS AND FINANCIAL STABILITY ON MARGINAL COST, THE LERNER INDES AND THE BOONE INDICATOR FOR LITED VS. NON-LISTED BANKS}

This table shows the results when a variation in financial stability, defined as the NPL ratio $\left(N P L_{i t}\right)$ and the natural logarithm of the $Z$-score $\left(\operatorname{Ln}\left(Z_{i t}\right)\right)$ regressed against the dependent variables, marginal cost $\left(M C_{i t}\right)$ in Panel $\mathrm{A}$, the Lerner index $\left(\right.$ Lerner $\left._{i t}\right)$ in Panel B, and the Boone indicator $\left(B_{h t}\right)$ in Panel C. The regressions are estimated using high-frequency data. $L_{i}$ is a qualitative variable that takes the value one if bank $i$ is listed and zero otherwise. Specifications (1), (2), (3) and (4) are estimated using the Ordinary Least Squares (OLS) estimator for panel data with fixed effects for the period 2002Q1-2016Q4. Specifications (5), (6), (7) and (8) are estimated using the Instrumental Variables (IV) estimator for the period 2008Q1-2016Q4. The selected instruments are the NPL ratio $\left(N P L_{i t}\right)$, the unemployment rate $\left(U N E M_{h . t-1}\right)$ and one-quarter-lagged 10-year sovereign $\operatorname{CDS}\left(C D S_{h . t-1}\right)$ for country $h$. Instruments validated by Sargan test, under the null of exogeneity, checking the lack of correlation between the instruments and the error term of the main equation. All the regressions contain control variables and individual fixed effects, and the standard errors are clustered by countries. *, **, $* * *$, denote minimum $10 \%, 5 \%, 1 \%$ significance, respectively.

\begin{tabular}{|c|c|c|c|c|c|c|c|c|}
\hline & \multicolumn{4}{|c|}{ OLS with fixed effects } & \multicolumn{4}{|c|}{ IV with fixed effects } \\
\hline & $\begin{array}{c}L_{i}=1 \\
(1)\end{array}$ & $\begin{array}{l}L_{i}=0 \\
(2)\end{array}$ & $\begin{array}{c}L_{i}=1 \\
(3)\end{array}$ & $\begin{array}{c}L_{i}=0 \\
(4)\end{array}$ & $\begin{array}{c}L_{i}=1 \\
(5)\end{array}$ & $\begin{array}{l}L_{i}=0 \\
(6)\end{array}$ & $\begin{array}{c}L_{i}=1 \\
(7)\end{array}$ & $\begin{array}{c}L_{i}=0 \\
(8)\end{array}$ \\
\hline \multicolumn{9}{|c|}{ Panel A: Dependent variable: Lerner $_{i t}$} \\
\hline$\Delta N P L_{i t}$ & $\begin{array}{l}-0.547 * * \\
(0.183)\end{array}$ & $\begin{array}{l}-0.732 * * \\
(0.213)\end{array}$ & & & $\begin{array}{l}-0.321 * * \\
(0.128)\end{array}$ & $\begin{array}{l}-0.363 * * \\
(0.139)\end{array}$ & & \\
\hline$\Delta \operatorname{Ln}\left(Z_{i t}\right)$ & & & $\begin{array}{l}0.114 * * \\
(0.013)\end{array}$ & $\begin{array}{l}0.161 * * \\
(0.011)\end{array}$ & & & $\begin{array}{l}0.353 * * * \\
(0.044)\end{array}$ & $\begin{array}{l}0.537 * * * \\
(0.065)\end{array}$ \\
\hline $\begin{array}{l}\text { Sargan test } \\
{[p \text {-value }]}\end{array}$ & & & & & 0.292 & 0.239 & 0.368 & 0.364 \\
\hline \multicolumn{9}{|c|}{ Panel B: Dependent variable: $B_{h t}$} \\
\hline$\Delta N P L_{i t}$ & $\begin{array}{l}-0.520 * * \\
(0.117)\end{array}$ & $\begin{array}{l}-0.569 * * \\
(0.116)\end{array}$ & & & $\begin{array}{l}-0.534 * * * \\
(0.116)\end{array}$ & $\begin{array}{l}-0.572 * * * \\
(0.121)\end{array}$ & & \\
\hline$\Delta \operatorname{Ln}\left(Z_{i t}\right)$ & & & $\begin{array}{l}0.324 * * * \\
(0.068)\end{array}$ & $\begin{array}{l}0.347 * * * \\
(0.080)\end{array}$ & & & $\begin{array}{l}0.278 * * * \\
(0.076)\end{array}$ & $\begin{array}{l}0.358 * * * \\
(0.082)\end{array}$ \\
\hline $\begin{array}{l}\text { Sargan test } \\
{[p \text {-value }]}\end{array}$ & & & & & 0.211 & 0.284 & 0.302 & 0.287 \\
\hline \multicolumn{9}{|c|}{ Panel C: Dependent variable: $M C_{h t}$} \\
\hline$\Delta N P L_{i t}$ & $\begin{array}{l}0.019 * * \\
(0.007)\end{array}$ & $\begin{array}{l}0.024 * * \\
(0.009)\end{array}$ & & & $\begin{array}{l}0.019 * * * \\
(0.004)\end{array}$ & $\begin{array}{l}0.024 * * * \\
(0.005)\end{array}$ & & \\
\hline$\Delta \operatorname{Ln}\left(Z_{i t}\right)$ & & & $\begin{array}{l}-0.001 * * \\
(0.000)\end{array}$ & $\begin{array}{l}-0.002 * * \\
(0.000)\end{array}$ & & & $\begin{array}{l}0.001 * * \\
(0.000)\end{array}$ & $\begin{array}{l}0.002 * * \\
(0.000)\end{array}$ \\
\hline $\begin{array}{l}\text { Sargan test } \\
{[p \text {-value }]}\end{array}$ & & & & & 0.824 & 0.746 & 0.242 & 0.250 \\
\hline $\mathrm{N}$ & 5.160 & 5.160 & 5.160 & 5.160 & 5.160 & 5.160 & 5.160 & 5.160 \\
\hline$X_{i, t-1}^{\prime}$ & Yes & Yes & Yes & Yes & Yes & Yes & Yes & Yes \\
\hline
\end{tabular}

Discussion.- The results of this study suggest that the examined transmission mechanism is relatively more sensitive for non-listed than for listed banks. Previous research has shown that an accumulation of NPLs on a bank's balance sheet reduces its profitability and asset value (Coccorese and Girardone, 2017; Zhang et al., 2016). Under current financial regulations, banks are required to hold a minimum capital buffer to fund new lending (Berger and Bouwman, 2013; Jiménez et al., 2017; Den Heuvel, 2008) $)^{14}$. Non-listed banks have com- 
paratively fewer options than listed banks do when it comes to raising capital in secondary markets, and are forced to obtain funding from deposits, securitization activities and interbank markets. Investors are therefore likely to harbour more doubts about the profitability and asset value and to demand more compensation for non-diversifiable risk from non-listed than from listed banks. In other words, higher input costs have a greater incremental effect on marginal cost and a greater decremental effect on lending in non-listed than in listed banks (Chiesa and Mansilla-Fernández, 2018 a,b). As a result, non-listed banks lose more lending market share than their competitors, and have to reduce their mark-ups to remain competitive.

\section{Conclusions}

This paper analyses the sensitivity of lending market competition to variations in the NPL ratio and the (inverse) probability of bank default, i.e., financial (in)stability. A unique database is constructed for this purpose by combining Bankscope accounting data (Bureau van Dijk) with Thomson Reuters Datastream macroeconomic and market data for each country in the Eurozone.

The main finding of this study is that higher NPL ratios and greater financial instability increase the level of competition in lending markets. In line with studies predicting than an increase in NPLs will increase banks' funding costs (Aiyar et al., 2015; Chiesa and Mansilla-Fernández, 2018 a,b), this paper shows that banks suffer both market share losses and mark-up losses due to an increase in marginal cost. The results of this study also suggest that market access can compensate for potential capital loss due to an increase in NPLs. To be specific, non-listed banks are economically more vulnerable than listed banks to a loss of market share.

As far as can be ascertained, this is one of the first studies to analyse the repercussions of financial stability for banking market competition. The results are robust to endogeneity tests. However, because data on 10-year sovereign CDS are available only from 2008 onwards, the analysis of their impact on the NPL ratio is limited to the crisis period. The effects of the sale of NPLs on secondary markets and the introduction of sovereign guarantees are issues which remain for future research.

\section{Notes}

1. European supervisors consider a loan to be doubtful when there are signs that the borrower will be unable to repay it within ninety days, not having paid any of the agreed instalments. In the worst case scenario, the borrower is unable to repay the loan and the bank has to write the loan off the balance sheet.

2. According to EBA data, in June 2018, the Eurozone countries with the highest non-performing loans ratios are Greece (44.81\%), Cyprus (34.12\%), Portugal (12.44\%), Italy (9.73\%), Ireland (7.01\%), and Spain (4.24\%).

3. The Basel -III accord requires banks to hold a minimum capital buffer for withstanding risk.

4. See Giannoccolo and Mansilla-Fernández (2017) for a more thorough review of the literature. 
5. The moral hazard hypothesis predicts that banks with low capital are relatively more prone to generate doubtful loans because they are able to increase the level of risk in their credit portfolios (a strategy known as gambling to resurrection) (see Berger and DeYoung, 1997; Bouwman and Malmendier, 2015).

6. Under the standard monopolistic competition model, a drop in credit demand can compensate for a possible price increase due to a marginal cost increase (see Kolmar, 2017; Pindyck and Rubinfeld, 2001). Accornero et al. (2017) show that an increase in the variation of the NPL ratio implies a reduction in the demand for loans. This result is due to economic slowdown (Balgova et al., 2016, 2018; Ghosh, 2017), the sovereign debt crisis (Buch et al., 2016; Podstawski and Velinov, 2018), and deleverage of the real sector during the crisis period (BdE, 2017) causing the loan demand curve to shift to the left.

7. Listed banks are usually larger in size, relatively more cost efficient, and have higher levels of market concentration than non-listed banks (e.g., Delis et al., 2017; Meslier et al., 2017; Phan et al., 2018).

8. The Eurozone countries are Germany, Austria, Belgium, Cyprus, Slovakia, Slovenia, Spain, Estonia, Finland, France, Greece, Holland, Ireland, Italy, Latvia, Lithuania, Luxembourg, Malta, and Portugal.

9. I am grateful for an anonymous reviewer's suggestions for calculating the price and the risk-adjusted marginal cost.

10. Jiménez et al. (2013), adopting the approach used by Martín-Oliver et al. (2006), use probability of default data $\left(P D_{i t}\right)$ from the Bank of Spain's Risk Information Centre.(CIR, for its acronym in). Access to the RIC not being possible, this study uses Bankscope accounting data instead.

11. Various studies calculate the leverage ratio as equity over total assets. The inverse enables interpretation of the ratio as the liabilities-to-equity ratio. The reasoning for this is as follows:

$$
\operatorname{LEV}_{i t}=\frac{\text { 'Liabilities'+'Equity' }}{\text { 'Equity' }}=\frac{\text { 'Liabilities' }}{\text { 'Equity' }}+1
$$

12. This mechanism has two component trends associated with the Banking Union: a cyclical component due to recent expectations of economic recovery and a clearing of balance sheets encouraging bankers to start planning for the future (Schoenmaker, 2015; Duijm and Schoenmaker, 2017); and a structural component due to the real sector's dependence on bank financing, and the coming Capital Markets Union (Langfield and Pagano, 2016). Banks prepare for new competition in the loans market -from mutual funds, pension funds and insurance companies, etc.- by upsizing and pursuing economies of scale through mergers (Evanoff and Ors, 2008).

13. The reader should recall that the higher the value of $Z_{i t}$, the lower bank default risk. This result suggests that non-listed banks assumed higher levels of risk than listed banks did during the study period.

14. Under the Basel-III accord, banks are required to hold a tier 1 common capital buffer and a capital conservation buffer equivalent to at least $4.5 \%$ and $2.5 \%$, respectively, of its risk-weighted assets. The following table summarizes the Basel-III reforms. Downloaded December 28, 2018: https://www.bis.org/bcbs/basel3/ b3_bank_sup_ reforms_es.pdf.

\section{References}

Accornero, M., Alessandri, P., Carpinelli, L. and Sorrentino, A. M. (2017), "Non-performing loans and the supply of bank credit: evidence from Italy", Questioni di Economia e Finanza (Occasional Papers) 374, Bank of Italy, Economic Research and International Relations Area.

Aiyar, S., Bergthaler, W., Garrido, J., Ilyina, A., Jobst, A., Kang, K., Kovtun, D., Liu, Y., Monaghan, D. and Moretti, M. (2015), “A Strategy for Resolving Europe's Problem Loans”, Staff discussion notes, International Monetary Fund.

Allen, F. and Gale, D. (2004), "Competition and financial stability", Journal of Money, Credit and Banking, 36: 453-480. 
Non-Performing Loans, Financial Stability, and Banking Competition: Evidence for Listed...

Angelini, P. (2018), “Do high levels of NPLs impair banks' credit allocation?”, Notes on financial stability and supervision, Bank of Italy.

Angelini, P., Bofondi, M. and Zingales, L. (2017), “The Origins of Italian NPLs”, Technical report, Mimeo.

Balgova, M., Nies, M. and Plekhanov, A. (2016), "The economic impact of reducing nonperforming loans", Technical report, European Bank for Reconstruction and Development.

Balgova, M., Plekhanov, A. and Skrzypinska, M. (2018), "Reducing non-performing loans: Stylized facts and economic impact", Technical report, Mimeo.

BdE (2017), Report on the financial and banking crisis in Spain, 2008-2014, Bank of Spain (BdE), May 2017.

Bending, T., Berndt, M., Betz, F., Brutscher, P., Nelvin, O., Revoltella, D., Slacik, T. and Wolski, M. (2014), "Unlocking lending in Europe", Economic report, European Investment Bank, EIB's Economics Department.

Berger, A. N. and Bouwman, C. H. (2013), "How does capital affect bank performance during financial crises?", Journal of Financial Economics, 109: 146-176.

Berger, A. N. and DeYoung, R. (1997), "Problem loans and cost efficiency in commercial banks", Journal of Banking Finance, 21: 849-870.

Boone, J. (2008), “A new way to measure competition”, The Economic Journal, 118: 1245-1261.

Bouwman, C. H. S. and Malmendier, U. (2015), “Does a bank's history affect its risk-taking?”, American Economic Review, 105: 321-25.

Boyd, J. H. and Gertler, M. (1994), "The role of large banks in the recent U.S. banking crisis", Quarterly Review, Win: 2-21.

Boyd, J. H. and Graham, S. L. (1998), Consolidation in U.S. banking: Implications for efficiency and risk, pp. 113-135. Boston, MA: Springer US.

Boyd, J. H. and Nicoló, G. D. (2005), "The theory of bank risk taking and competition revisited", The Journal of Finance, 60: 1329-1343.

Buch, C. M., Koetter, M. and Ohls, J. (2016), "Banks and sovereign risk: A granular view”, Journal of Financial Stability, 25: 1-15.

Cai, J., Eidam, F., Saunders, A. and Steffen, S. (2018), "Syndication, interconnectedness, and systemic risk", Journal of Financial Stability, 34: 10-20.

Carbó, S., Humphrey, D., Maudos, J. and Molyneux, P. (2009), "Cross-country comparisons of competition and pricing power in European banking", Journal of International Money and Finance, 28: $115-134$.

Carbó-Valverde, S., Humphrey, D. and Rodríguez-Fernández, F. (2003), "Deregulation, bank competition and regional growth", Regional Studies, 37: 227-237.

Carbó-Valverde, S. and Rodríguez-Fernández, F. (2007), "The determinants of bank margins in European banking", Journal of Banking and Finance, 31: 2043-2063, Developments in European Banking.

Carbó-Valverde, S., Rodríguez-Fernández, F. and Udell, G. F. (2009), "Bank market power and SME financing constraints", Review of Finance, 13: 309-340. 
Chiesa, G. and Mansilla-Fernández, J. M. (2018 a), "Disentangling the transmission channel NPLs-cost of capital-lending supply", Applied Economics Letters, forthcoming.

Chiesa, G. and Mansilla-Fernández, J. M. (2018b), "Non-Performing Loans, Cost of Capital, and Lending Supply: Lessons from the Eurozone Banking Crisis", Departmental Working Papers 2018-05, Department of Economics, Management and Quantitative Methods at Università degli Studi di Milano.

Coccorese, P. (2004), "Banking competition and macroeconomic conditions: a disaggregate analysis", Journal of International Financial Markets, Institutions and Money, 14: 203-219.

Coccorese, P. and Girardone, C. (2017), "Bank capital and profitability: Evidence from a global sample", Working Paper, Essex Finance Centre Working Papers, Colchester.

Cruz-García, P., Fernández de Guevara, J. and Maudos, J. (2017), "The evolution of market power in European banking", Finance Research Letters, 23: 257-262.

Cruz-García, P., Fernández de Guevara, J. and Maudos, J. (2018), "Concentración y competencia en bancarias en España: El impacto de la crisis y la reestructuración”, Revista de Estabilidad Financiera (Bank of Spain), 34: 61-80.

Degryse, H. and Ongena, S. (2008), "Competition and regulation in the banking sector: A review of the empirical evidence on the sources of bank rents", in A. V. Thakor and A. W. Boot (eds.), Handbook of Financial Intermediation and Banking, Handbooks in Finance, 483-554. San Diego: Elsevier.

Delis, M. D., Hasan, I., Kokas, S., Liu, L. and Mylonidis, N. (2017), "Bank market power and loan growth", in J. A. Bikker and L. Spierdijk (eds.), Handbook of Competition in Banking and Finance, Chapter 18, 383-400. Elgar.

Den Heuvel, S. J. V. (2008), "The welfare cost of bank capital requirements", Journal of Monetary Economics, 55: 298-320.

Duijm, P. and Schoenmaker, D. (2017), "European Banks Straddling Borders: Risky or Rewarding?", CEPR Discussion Papers 12159.

Evanoff, D. D. and Ors, E. (2008), "The competitive dynamics of geographic deregulation in banking: Implications for productive efficiency", Journal of Money, Credit and Banking, 40: 897-928.

Ghosh, A. (2017), "Sector-specific analysis of non-performing loans in the us banking system and their macroeconomic impact", Journal of Economics and Business, 93: 29-45.

Giannoccolo, P. and Mansilla-Fernández, J. M. (2017), "Bank Restructuring, Competition, and Lending Supply: Evidence from the Spanish Banking Sector”, Departmental Working Papers 2017-16, Department of Economics, Management and Quantitative Methods at Università degli Studi di Milano.

Hellmann, T. F., Murdock, K. C. and Stiglitz, J. E. (2000), "Liberalization, moral hazard in banking, and prudential regulation: Are capital requirements enough?", American Economic Review, 90: 147-165.

IJtsma, P., Spierdijk, L. and Shaffer, S. (2017), "The concentration-stability controversy in banking: New evidence from the EU-25", Journal of Financial Stability, 33: 273-284.

Jiménez, G., López, J. A. and Saurina, J. (2013), "How does competition affect bank risk-taking?", Journal of Financial Stability, 9: 185-195.

Jiménez, G., Ongena, S., Peydró, J.-L. and Saurina, J. (2017), “Macroprudential policy, countercyclical bank capital buffers, and credit supply: Evidence from the Spanish dynamic provisioning experiments", Journal of Political Economy, 125: 2126-2177. 
Köhler, M. (2015), "Which banks are more risky? The impact of business models on bank stability", Journal of Financial Stability, 16: 195-212.

Kolmar, M. (2017), Principles of Microeconomics, Springer.

Laeven, L. and Levine, R. (2009), "Bank governance, regulation and risk taking”, Journal of Financial Economics, 93: 259-275.

Langfield, S. and Pagano, M. (2016), "Bank bias in Europe: Effects on systemic risk and growth", Economic Policy, 31: 51-106.

Liu, H., Molyneux, P. and Wilson, J. O. (2013), "Competition and stability in European banking: A regional analysis", The Manchester School, 81: 176-201.

Louzis, D. P., Vouldis, A. T. and Metaxas, V. L. (2012), "Macroeconomic and bank-specific determinants of non-performing loans in Greece: A comparative study of mortgage, business and consumer loan portfolios", Journal of Banking Finance, 36: 1012-1027.

Martín-Oliver, A., Salas-Fumás, V. and Saurina, J. (2006), "Risk premium and market power in credit markets", Economics Letters, 93: 450-456.

Martinez-Miera, D. and Repullo, R. (2010), “Does competition reduce the risk of bank failure?", Review of Financial Studies, 23: 3638-3664.

Maudos, J. and Fernández de Guevara, J. (2004), "Factors explaining the interest margin in the banking sectors of the European Union", Journal of Banking and Finance, 28: 2259-2281.

Maudos, J. and Fernández de Guevara, J. (2007), “The cost of market power in banking: Social welfare loss vs. cost inefficiency”, Journal of Banking and Finance, 31: 2103-2125, Developments in European Banking.

Meslier, C., Risfandy, T. and Tarazi, A. (2017), "Dual market competition and deposit rate setting in Islamic and conventional banks", Economic Modelling, 63: 318-333.

Mohaddes, K., Raissi, M. and Weber, A. (2017), "Can Italy grow out of its NPL overhang? A panel threshold analysis", Economics Letters, 159: 185-189.

Nier, E. and Baumann, U. (2006), "Market discipline, disclosure and moral hazard in banking", Journal of Financial Intermediation, 15: 332-361, "Basel II: Accounting, Transparency and Bank Stability".

Phan, H. T., Anwar, S. and Alexander, W. R. J. (2018), "The determinants of banking efficiency in Hong Kong 2004-2014”, Applied Economics Letters, 25: 1323-1326.

Pindyck, R. and Rubinfeld, D. (2001), Microeconomics, Economics Series, Prentice Hall.

Podstawski, M. and Velinov, A. (2018), "The state dependent impact of bank exposure on sovereign risk", Journal of Banking and Finance, 88: 63-75.

Rud, O. A., Rabanal, J. P. and Horowitz, J. (2018), "Does competition aggravate moral hazard? A multi-principal-agent experiment”, Journal of Financial Intermediation, 33: 115-121.

Salas, V. and Saurina, J. (2002), "Credit risk in two institutional regimes: Spanish commercial and savings banks", Journal of Financial Services Research, 22: 203-224.

Schaeck, K., Cihak, M., Maechler, A. and Stolz, S. (2012), “Who disciplines bank managers?”, Review of Finance, 16: 197-243. 
Schoenmaker, D. (2015), “The new Banking Union landscape in Europe: Consolidation ahead?”, Journal of Financial Perspectives, 3: 189-201.

Stern, G. H. and Feldman, R. J. (2004), Too Big to Fail: The Hazards of Bank Bailouts, Brookings Institution Press.

VanHoose, D. (2017), The Industrial Economics of Banking, pp. 47-88, Berlin, Heidelberg: Springer Berlin Heidelberg.

Zhang, D., Cai, J., Dickinson, D. G. and Kutan, A. M. (2016), "Non-performing loans, moral hazard and regulation of the Chinese commercial banking system", Journal of Banking and Finance, 63: 48-60.

\section{Resumen}

Este trabajo analiza los efectos de la morosidad crediticia y de la (in)estabilidad financiera sobre la competencia bancaria en los mercados de crédito de la zona euro. Los resultados sugieren que la morosidad bancaria incrementa el coste marginal y el grado de competencia de los mercados bancarios. Este fenómeno es económicamente más significativo para los bancos no cotizados que para los bancos cotizados. Los resultados son robustos a posibles problemas de endogeneidad derivados de la recesión económica y de la crisis de deuda soberana sobre el crecimiento de la morosidad.

Palabras clave: Bancos cotizados, competencia bancaria, crisis financiera y bancaria, deuda soberana, NPLs.

Clasificación JEL: G01, G21, G32, H63. 